\title{
Operative Illustrations of the Osborne's Ligament
}

\author{
Osborne Ligamanımn Ameliyat Fotoğrafları
}

Serkan SIMSEK, Uygur ER, Adnan DEMIRCI, Mehmet SORAR

M.H. Diskapi Yildirim Beyazit Education and Research Hospital, 2nd Neurosurgery Clinic, Ankara, Turkey

Correspondence address: Uygur ER / E-mail: uygurer@gmail.com

\begin{abstract}
The cubital tunnel syndrome is widely considered as the second most frequent compression neuropathy in the upper extremities although the existence of a compressive cause has not been determined conclusively. As far as we know, operational photography of compression of the ulnar nerve at the elbow is almost never found in the literature. In this paper, operational and pathological photographs of the Osborne's ligament as a cause of ulnar entrapment neuropathy at the elbow are presented. There is still an ambiguity as to whether compressive or tractional etiology or both of these factors may occur progressively to be a factor in the development of neuropathy. This report may be considered as concrete evidence for the compressive etiology for ulnar neuropathies.
\end{abstract}

KEYWORDS: Cubital tunnel syndrome, Osborne's ligament, Ulnar neuropathy

\section{öz}

Bası nedenleri henüz tam olarak ortaya konmadığı halde, Kübital tünel sendromu genel olarak üst ekstremitelerin en sık ikinci basıya bağlı nöropatisi olarak kabul edilmektedir. Bilebildiğimiz kadarıyla literatürde ulnar sinirin bilekte basısına ait ameliyat fotoğrafı ilgili İngilizce yazında mevcut değildir. Bu yazıda ulnar tuzak nöropatinin bir nedeni olarak kabul edilen Osborne ligamanının ameliyat sırasındaki fotoğrafları ve patolojik spesimenleri sunulmuştur. Tuzak nöropati gelişiminde gerilme kuvvetlerinin mi, basının mı yoksa her ikisinin birden mi rol oynadığı ve gelişiminin nasıl olduğu hakkında hala belirsizlik vardır. Bu rapor bilekte ulnar tuzak nöropati etiyolojisinde basının yer aldığına bir dayanak olabilir.

ANAHTAR SÖZCÜKLER: Kübital tünel sendromu, Osborne ligamanı, Ulnar nöropati

\section{INTRODUCTION}

The cubital tunnel syndrome (CTS) is widely considered as the second most frequent compression neuropathy in the upper extremities $(1,3)$. Osborne described a fibrous band as a cause of compression neuritis at the elbow (4). However, existence of a compressive cause has not been determined conclusively since then. There is still a disagreement as to whether compressive or tractional etiology or both of these factors may occur progressively to be a factor in the neuropathy. As far as we know, visual material about compression of the ulnar nerve at the elbow is almost never found in the literature. In this paper, operational and pathological photographs of the Osborne's ligament as a cause of ulnar entrapment neuropathy at the elbow are presented.

\section{CASE REPORT}

A 64-year old woman applied to the hospital with pain in the medial aspect of right elbow for at least 1 year. The pain worsened with elbow flexion. In addition, the patient had numbness in the palm and fingers. According to the Mc Gowen classification, the patient had a grade 3 ulnar neuropathy. An electroneuromyography (ENMG) revealed compressive ulnar neuropathy at the right elbow with almost total axonal degeneration of the ulnar nerve. Absolute motor nerve conduction velocity (NCV) of the ulnar nerve was less than $30 \mathrm{~m} / \mathrm{sec}$. The patient had no cervical neuropathy or shoulder pathology. She was operated for decompression of the nerve at the elbow. After exposure of the nerve, a ligament compressing the nerve was seen between the two heads of the flexor carpi ulnaris (Figure 1A). In situ decompression was performed by cutting a ligament over the nerve (Figure 1B). A piece of ligament sample was taken for histological investigation. Connective tissue cells within collagen fibrils were observed under the light microscopy with hematoxylin and eosin stain (Figure 2). Immediately after operation, numbness of the patient resolved. Motor functions improved partly one day later and completely recovered after one week. A control ENMG after one month showed markedly recovery and regeneration. NCV of the ulnar nerve was more than 42 $\mathrm{m} / \mathrm{sec}$.

\section{DISCUSSION}

Frictional or traction ulnar neuritis of the elbow have been taken into account as etiological factors, as well as recurrent elbow joint dislocation causing stretching the nerve (4). During elbow flexion, the volume or radius of the cubital tunnel decreases physiologically, so moderate compression of the nerve within the tunnel can be observed as normal and 

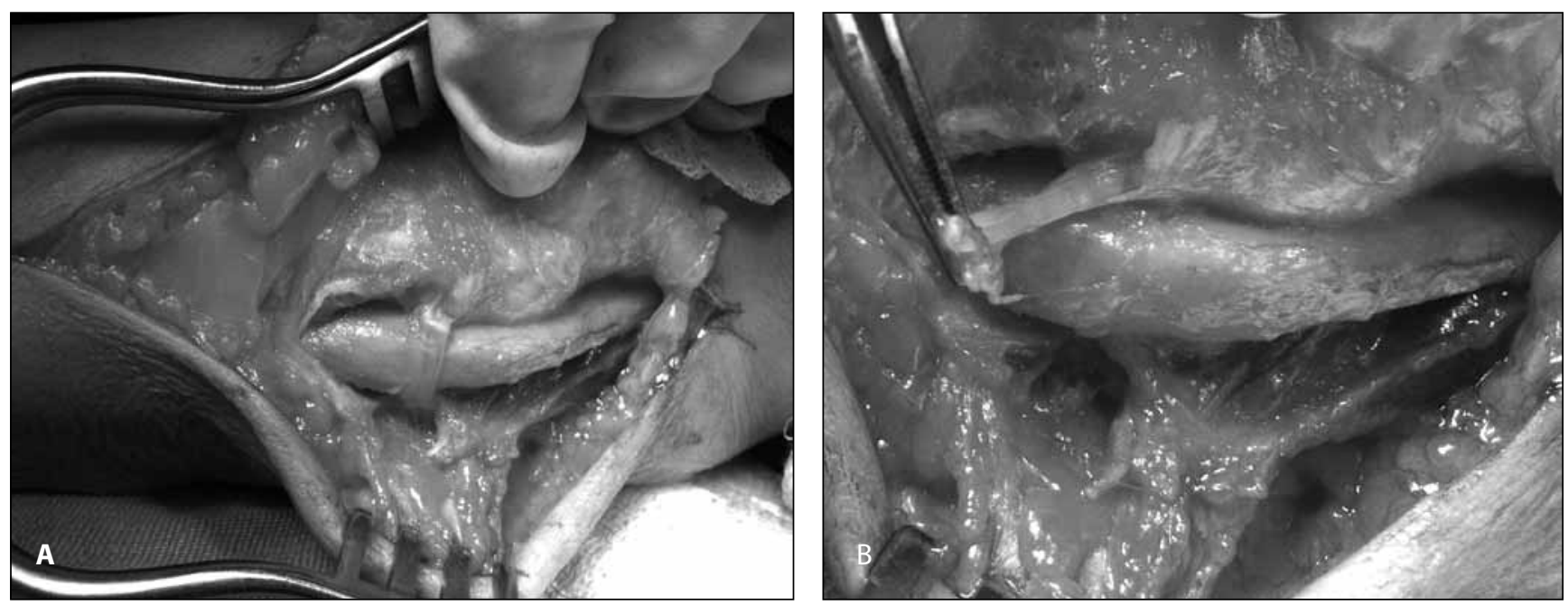

Figure 1: Operative photograph of a fibrous band compressing the ulnar nerve $\mathbf{A}$ ) and after decompression of the nerve $\mathbf{B}$ ).

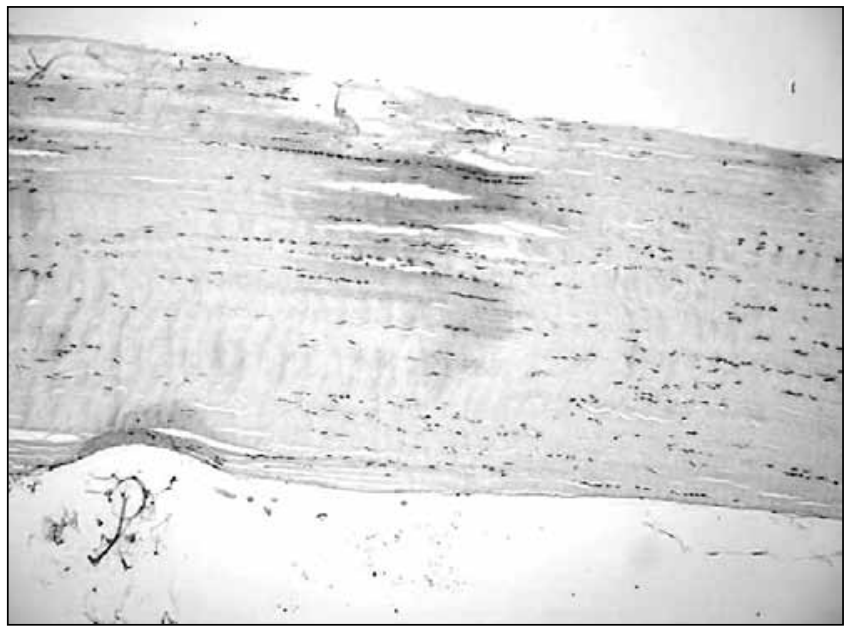

Figure 2: Pathology specimen of the band (HE, 10x). Connective tissue cells with collagen fibrils are seen.

may not result in neuropathy. Entrapments of the ulnar nerve occur at four sites. The arcade of Struthers is a well known compressive etiology for CTS above the elbow. Guyon's canal at the wrist and retroepicondylar groove at the elbow are other sites of entrapment for the ulnar nerve. Compression by fascia may be the cause of entrapment here. Just distal to the ulnar groove, under the aponeurosis between the heads of the flexor carpi ulnaris, is the fourth site of compression (2). Another concept for ulnar nerve injury within or just distal to the cubital tunnel is the dynamic compression or repetitive trauma. Decrease in the volume of the cubital tunnel secondary to an increase in the flexion of the elbow may result in compression of the ulnar nerve (6). CTS may also arise from a pathological compression of the nerve within the tunnel by an abnormal fibrous band. A transverse fibrous band bridging the two heads of the musculus flexor carpi ulnaris forms the firm passage for the ulnar nerve. The band tightens during flexion of the elbow and allows the capsular floor of the nerve to protrude into the tunnel, so the compression may occur transversely under the band. The band is considered as an epicondylo-olecranon ligament (5). It is possible to differentiate between normal and compressed nerve radiologically within the cubital tunnel especially by MRI (1). However, showing the epicondylo-olecranon ligament is not possible by the same technique as far as we know. The NCV study after surgery revealed that ulnar nerve conduction velocity had increased more than $10 \mathrm{~m} / \mathrm{sec}$. This shows us that the fibrous band seen at the surgery is likely to be the etiological factor of the compression. Rapid resolution of the sensorimotor symptoms of the patient also supports our opinion.

Surgical and pathological photographs of Osborne's band are presented in this paper. This report may be considered as concrete evidence for the compressive etiology for ulnar neuropathies.

\section{REFERENCES}

1. Andreisek G, Crook DW, Burg D, Marincek B, Weishaupt D: Peripheral neuropathies of the median, radial, and ulnar nerves: MR imaging features. Radio Graphics 26:1267-1287, 2006

2. Greenberg MS: Peripheral neuropathies. In: Greenberg MS, ed. Handbook of Neurosurgery. Seventh Ed. New York: Thieme 2010, 793-822

3. Iba K, Wada T, Aoki M, Tsuji H, Oda T, Yamashita T: Intraoperative measurement of pressure adjacent to the ulnar nerve in patients with cubital tunnel syndrome. J Hand Surg 31-A(4):553-558, 2006

4. Osborne G: Ulnar neuritis. Postgrad Med J 35:392-396, 1959

5. Spinner RJ, Amadio PC: Compressive neuropathies of the upper extremity. Clin Plast Surg 30:155-173, 2003

6. Szabo R: Compression neuropathies of the ulnar nerve. In: Green DP, Hotchkiss RN, Pederson WC, eds. Green's operative hand surgery. Vol 1 4th ed. New York: Churchill Livingstone, 1999, 1422-1429 